\title{
CULTURA JUVENIL: CONSUMO E PRODUÇÃO EM DESENHO, MÚSICA E TEATRO.
}

\section{Ana J. B. de Brito*, Elisa C. de Souza*, Fernanda L. M. Silva*, Guilherme G. de Sousa*, Isabelly T. K. Santos*,} Kaio H. S. Dias*, Profa. Dra. Mara R. Ferraro Nita, Profa. Dra. Patricia R. Cortelazzo.

\section{Resumo}

Este PIBIC-EM realizado entre 2018/2019, no Colégio Técnico de Campinas (COTUCA), teve por objetivo maior investigar como se dá o consumo e a produção artística do aluno de Ensino Médio, por meio de três linguagens: o desenho, a música e o teatro. Para tanto, os alunos participantes do projeto ofereceram para a comunidade escolar, semanalmente, oficinas de violão, violino, teatro, desenho e desenho digital, bem como realizaram pesquisa que traçou o perfil das práticas artísticas e culturais de estudantes do colégio. Esta pesquisa-ação foi embasada em Barbosa (2018), Edwards (2002), Erimilson (2007) e Spolin (2014).

\section{Palavras-chave:}

arte, adolecência, cultura juvenil

\section{Introdução}

Os estudantes do COTUCA têm uma rotina de estudos desgastante, com poucos momentos para descontração, criação e apreciação artística. Por meio deste projeto, procuramos investigar como os jovens alunos se relacionam com as artes visuais, as artes cênicas e a música, enquanto consumidores e produtores, bem como dar visibilidade ao papel formativo da arte no ambiente escolar.

\section{Resultados e Discussão}

Os resultados da intervenção artística, via oficinas semanais, foram bastante positivos. Os alunos que possuíam o traço mais infantilizado, por exemplo, atingiram certo amadurecimento gráfico. Os estudantes participantes das oficinas de violino e violão, por outro lado, iniciaram-se na leitura da partitura e aprenderam a tocar efetivamente trechos de composições. Em teatro, destacou-se a apresentação das peças $O$ beijo no asfalto (1960) de Nelson Rodrigues e As branquelas (2004) de Keenen Ivory Wayans. A coleta de dados, realizada através de Formulário Google, permitiu traçar um perfil das práticas artísticas e culturais dos estudantes que, predominantemente, escutam música no Youtube e no Spotify; tem por atores favoritos Johnny Depp e Robert Downey Jr; e cujas referências visuais sobrevém dos quadrinhos e da animação.

Figura 1. Oficinas de Desenho vetorial e teatro.
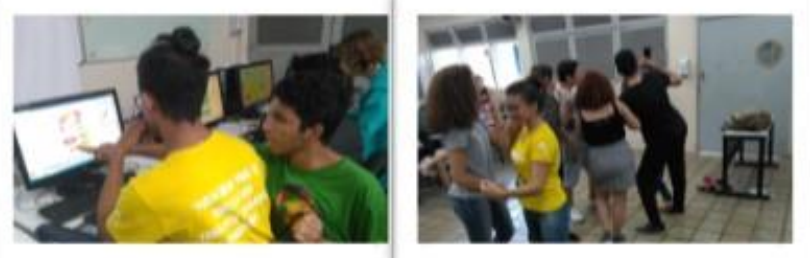

Figura 2. Oficinas de violão, desenho, violino e apresentação teatral

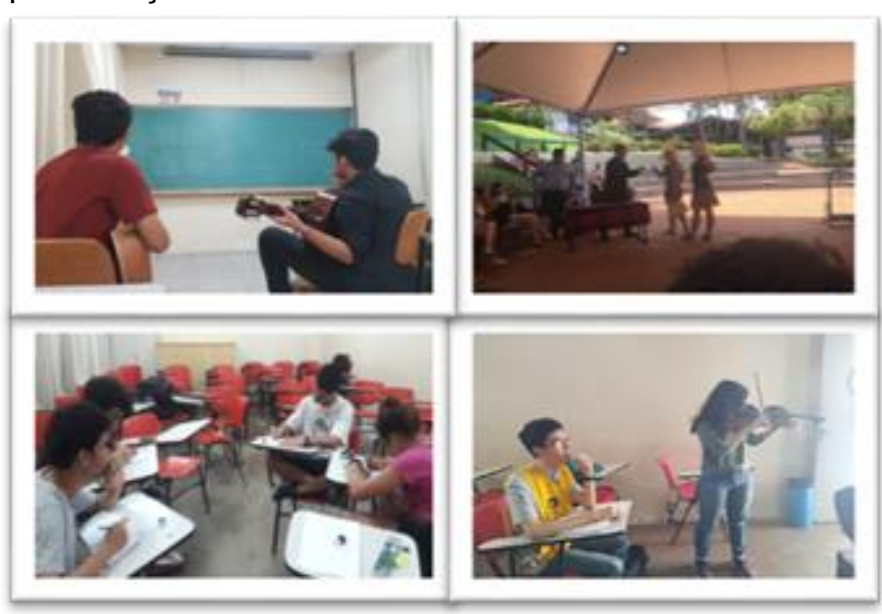

\section{Conclusões}

Observou-se que o projeto impactou a rotina estressante dos alunos inscritos nas oficinas, propiciando momentos de descontração e oferecendo possiblidade sensíveis e poéticas de comunicação e expressão. Conclui-se, portanto, que as manifestações artísticas e culturais devam estar mais presentes no cotidiano dos alunosadolescentes do ensino médio.

\section{Agradecimentos}

Às professoras orientadoras, Profa. Dra. Mara R. Ferraro Nita e Profa. Dra. Patricia R. Cortelazzo; ao CNPq e PIBIC-EM pelo financiamento da pesquisa; aos estudantes e à direção do COTUCA.

BARBOSA, Ana Mae. O dilema das Artes no Ensino Médio no Brasil. POS: Revista do Programa de Pós-graduação em Artes da EBA/UFMG. V.7, n.13: mai.2017. Disponível em: https://www.eba.ufmg.br/revistapos/index.php/pos/article/view/578/251. Acesso em 05 mar. 2018.

EDWARDS, Betty. Desenhando com o lado direito do cérebro. Tradução de Ricardo Silveira. 4. ed. Rio de Janeiro: Ediouro, 2002.

ERIMILSON. CURSO PRÁTICO DE VIOLÃO BÁSICO. - $5^{\mathrm{a}}$ ed.- São Paulo: copyright, 2007

SPOLIN, Viola. Jogos Teatrais. O Fichário de Viola Spolin. - $2^{\mathrm{a}}$ ed. - São Paulo, SP; Perspectiva, 2014. 